\title{
17-Year-Long Sewage Sludge Ash Concrete Exposure Test
}

\author{
Koichi Kobayashi * (D) and Wataru Koyanagi \\ Department of Civil Engineering, Gifu University, Gifu 5011193, Japan; wkyng@wind.sannet.ne.jp \\ * Correspondence: ko2ba@gifu-u.ac.jp
}

\begin{abstract}
This study was conducted on concrete using sewage sludge ash (SSA) with the aim to establish an efficient use of SSA as a cement replacement material. Concrete specimens with three degrees of strength were made from two different SSAs and exposed in temperate plain and cold mountain regions for a prolonged period of time to investigate the long-term properties of SSA concrete. After 17 years of exposure, the properties of the specimens were examined. SSA concrete basically maintained its strength after 17 years of exposure. No significant drop in the relative dynamic modulus of elasticity was detected in SSA concrete left in a cold mountain region, despite the fact that it would be exposed to a considerable number of freeze-and-thaw cycles. It was also confirmed that the SSA concrete exhibited high resistance against carbonation. A small amount of Katoite formed in the hardened cement/SSA mixture, probably due to the high content of $\mathrm{Al}_{2} \mathrm{O}_{3}$ in SSA. No abnormal formation of ettringite was observed.
\end{abstract}

Keywords: sewage sludge ash; exposure test; carbonation; SEM observation; XRD analysis

Citation: Kobayashi, K.; Koyanagi, W. 17-Year-Long Sewage Sludge Ash Concrete Exposure Test. Infrastructures 2021, 6, 74. https:// doi.org/10.3390/infrastructures 6050074

Academic Editors: Suvash Chandra Paul and Gideon van Zijl

Received: 23 April 2021

Accepted: 10 May 2021

Published: 11 May 2021

Publisher's Note: MDPI stays neutral with regard to jurisdictional claims in published maps and institutional affiliations.

Copyright: (C) 2021 by the authors. Licensee MDPI, Basel, Switzerland. This article is an open access article distributed under the terms and conditions of the Creative Commons Attribution (CC BY) license (https:// creativecommons.org/licenses/by/ $4.0 /)$.

\section{Introduction}

The sewage sludge output has been increasing with the improvement of sewage systems and the application of advanced treatment technologies such as the anaerobicanoxic-aerobic (A2O) process. The annual industrial waste amounts to $375 \times 10^{6}$ tons in Japan (2018), about $20 \%$ of which is taken up by sewage sludge $\left(77,445 \times 10^{3}\right.$ tons); therefore, it is urgently needed to find an efficient use of the sludge. Since the sewage sludge ash (hereafter, SSA) contains silicon dioxide $\left(\mathrm{SiO}_{2}\right)$ and calcium oxide $(\mathrm{CaO})$, about a quarter of the annual sludge mass is used as a raw material for cement clinker. SSA in the form of a fine powder has the potential to be used directly as a replacement material for cement rather than as a raw material for cement clinker. However, care must be taken in the use of SSA as a concrete admixture, because it contains unwanted substances such as phosphorus compounds that interfere with the cement setting process.

Bhatty et al. were among the very first who investigated the possible use of SSA as a concrete admixture [1]. They conducted a strength test on mortar mixtures with $50 \%$ of sand replaced with fly ash or SSA, and found that, while the mortar with fly ash showed an increase in strength, the mortar with SSA showed reduced strength. Monzo et al. replaced $15 \%$ of cement with SSA in mortar and found that the mortar had a higher strength than the control mixture at an age from 7 to 28 days. They also discovered that the flowability of the mortar was reduced because of the irregular morphology of SSA [2]. Cyr et al. used mortars with $25 \%$ and $50 \%$ of cement replaced with SSA and discovered that the replacement caused delays in setting and hydration of $1.5 \mathrm{~h}$ and $3.0 \mathrm{~h}$, respectively, for the $25 \%$ SSA and $50 \%$ SSA mixtures. The compressive strength development of mortars within 28 days was also affected. It was shown that the leaching behavior of mortars containing SSA was of the same order of magnitude as that of the reference mortar [3]. Mejdi et al. clarified that the delay in setting and the reduced early age strength were caused by orthophosphoric acid that slowed down the hydration of cement, in particular of alite $\left(\mathrm{C}_{3} S\right)$ [4].

Lynn et al. concluded, based on a literature survey, that the SSA satisfied the standard pozzolanic activity measures in the majority of cases and, in this regard, it was comparable 
to fly ash. In mortar and concrete mixes, using the SSA as a direct cement replacement results in lower strength and workability [5]. According to Chen et al., the pozzolanic reactivities of SSA and fine SSA are weaker than that of fly ash. However, at the same replacement level of up to $20 \%$, the compressive and flexural strengths of mortars containing these three admixtures are comparable [6].

Chakraborty proposes a composition of alkali-activated SSA, which is prepared by mixing SSA with quick lime and BFS and for which sodium hydroxide is used as the alkali activator [7]. Another usage is the fabrication of bricks for construction purposes from SSA combined with waste glass, as shown by Lu et al. [8].

The examples described in diverse studies of the possible uses of SSA reported above indicate the high potential of SSA as a construction material. In Japan, Koyanagi et al. led research studies on concrete with the use of SSA from 1998 to 1999 [9-11] and started an exposure test with the goal to clarify the long-term durability of SSA concrete. In 2016, we had an opportunity to perform various tests on the concrete specimens that had been exposed for 17 years and report here the results drawn from those data. This paper was completely revised and reconstructed from our previous report [12], with new added contents.

\section{Overview of the Materials}

In this study, two types of SSAs produced by two different sewage treatment plants were used $[10,11]$. Tables 1 and 2 show the results of the chemical analysis conducted according to the procedure specified by Japan Cement Association [13,14]. Both SSAs had a similar composition to that of pozzolan, i.e., fly ash, mainly composed of silicon dioxide $\left(\mathrm{SiO}_{2}\right)$, aluminum oxide $\left(\mathrm{Al}_{2} \mathrm{O}_{3}\right)$, and calcium oxide $(\mathrm{CaO})$. They contained a significant amount of phosphorus pentoxide $\left(\mathrm{P}_{2} \mathrm{O}_{5}\right)$. No chloride was detected.

Table 1. Chemical Compositions of SSAs (\%) [10].

\begin{tabular}{lcccccccc}
\hline & $\mathbf{S i O}_{\mathbf{2}}$ & $\mathbf{A l}_{\mathbf{2}} \mathbf{O}_{\mathbf{3}}$ & $\mathbf{C a O}$ & $\mathbf{S O}_{\mathbf{3}}$ & $\mathbf{N a}_{\mathbf{2}} \mathbf{O}$ & $\mathbf{K}_{\mathbf{2}} \mathbf{O}$ & $\mathbf{P}_{\mathbf{2}} \mathbf{O}_{\mathbf{5}}$ & $\mathbf{C l}^{-}$ \\
\hline SSA-A & 36.8 & 20.2 & 8.7 & 1.11 & 0.50 & 1.75 & 13.7 & 0.0 \\
SSA-B & 34.2 & 21.1 & 7.2 & 0.27 & 0.65 & 1.83 & 23.5 & 0.0 \\
OPC * & 21.1 & 5.1 & 64.0 & 1.8 & 0.29 & 0.60 & 0.2 & 0.0 \\
\hline
\end{tabular}

* Ordinary Portland cement used in the trial test in the previous year.

Table 2. Minor Heavy Metal Components in SSA (ppm) [10].

\begin{tabular}{ccccccc}
\hline & $\mathbf{P b}$ & $\mathbf{C d}$ & $\mathbf{H g}$ & As & Se & Total-Cr \\
\hline SSA-A & 88 & 3.2 & ND & 7.5 & 0.37 & 63 \\
SSA-B & 210 & 7.4 & ND & 4.9 & 0.03 & 350 \\
\hline
\end{tabular}

Two elution tests outlined in Table 3 were conducted to determine the elution behavior of the heavy metals contained in the sludge ashes. The results are shown in Table 4. Considering the negligible amounts of eluted heavy metals, it was concluded that the heavy metal content would not cause serious problems in using the SSAs as a concrete admixture based on the fact that the ashes would take up only $10 \%$ of the cement component of the concrete mixture (as will be described later) and that the metals would be solidified by cement hydrates.

Figure 1 shows that the two ashes, SSA-A and SSA-B, had slightly different distributions of X-ray powder diffraction intensities [10]. SSA-A presented a lower quartz peak, around $2 \theta=27^{\circ}$ than SSA-B. The reduced crystallinity of silicone dioxide in SSH-A is attributable to the incineration temperature of $850^{\circ} \mathrm{C}$ in the production of SSA-A as compared to $800^{\circ} \mathrm{C}$ for SSA-B. Both SSA-A and SSA-B had very irregular shapes, as can be seen in Figure 2 [10]. The particle size distributions of the two ashes in comparison to ordinary Portland cement (OPC) are shown in Figure 3. Both SSAs presented larger particle size than Portland cement, and SSA-B was larger in size than SSA-A. 
Table 3. Overview of Heavy Metal Elution Tests [10].

\begin{tabular}{ccc}
\hline & Test $\mathbf{~}^{*}$ & Test $\mathbf{~}^{*}$ \\
\hline Sample preparation & Crushed $(<\phi 5 \mathrm{~mm})$ & As it is \\
\hline Solvent & $\begin{array}{c}\text { Deionized water } \\
\text { (initial } \mathrm{pH}=5.8-6.3)\end{array}$ & $\begin{array}{c}\text { Deionized water saturated with } \mathrm{CO}_{2} \\
\text { (initial } \mathrm{pH} 4.0)\end{array}$ \\
\hline $\mathrm{pH}$ control & None & None \\
\hline Elute/sample ratio & $10: 1$ & $10: 1$ \\
\hline Elution method & Horizontal shake at $200 \mathrm{~Hz}$ for $6 \mathrm{~h}$ & Stirred at 200 rpm for $24 \mathrm{~h}$ \\
\hline Filtration & $\phi 1$ micron & $\phi 0.45$ micron \\
\hline
\end{tabular}

* Test 1: Method according to the Japan Environmental Agency, Test 2: Method according to the Public Works Research Institute.

Table 4. Results of Heavy Metal Elution Tests (\%) [10].

\begin{tabular}{ccccc}
\hline & \multicolumn{2}{c}{ SSA-A } & \multicolumn{2}{c}{ SSA-B } \\
\hline $\mathrm{Pb}$ & Test 1 & Test 2 & Test 1 & Test 2 \\
\hline $\mathrm{Cd}$ & $\mathrm{ND}$ & $\mathrm{ND}$ & ND & ND \\
\hline $\mathrm{Hg}$ & $\mathrm{ND}$ & $\mathrm{ND}$ & $\mathrm{ND}$ & ND \\
\hline $\mathrm{As}$ & 0.055 & $\mathrm{ND}$ & $\mathrm{ND}$ & ND \\
\hline $\mathrm{Se}$ & 0.056 & 0.135 & 0.014 & 0.067 \\
\hline $\mathrm{Cr}(\mathrm{VI})$ & $\mathrm{ND}$ & 0.094 & 0.002 & 0.004 \\
\hline & & $\mathrm{ND}$ & $\mathrm{ND}$ & $\mathrm{ND}$ \\
\hline
\end{tabular}

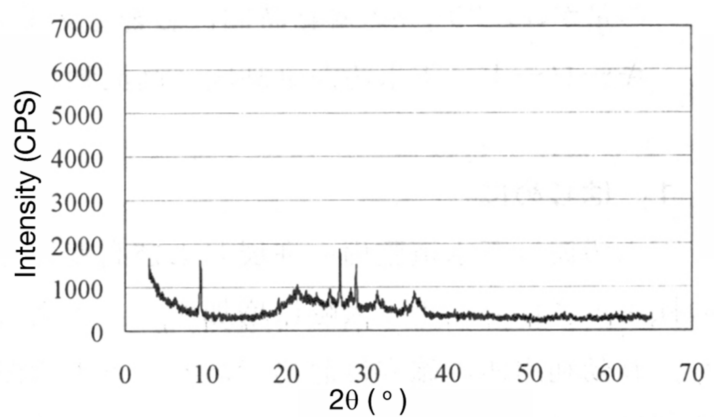

(a) SSA-A

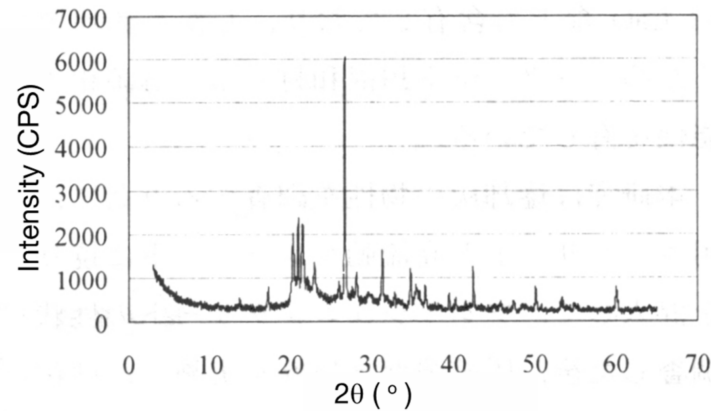

(b) SSA-B

Figure 1. X-ray powder diffraction (a) SSA-A, (b) SSA-B [10].

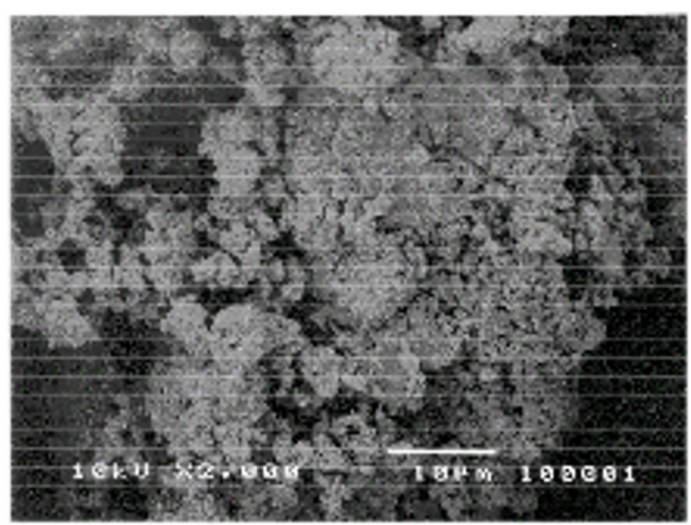

(a) SSA-A

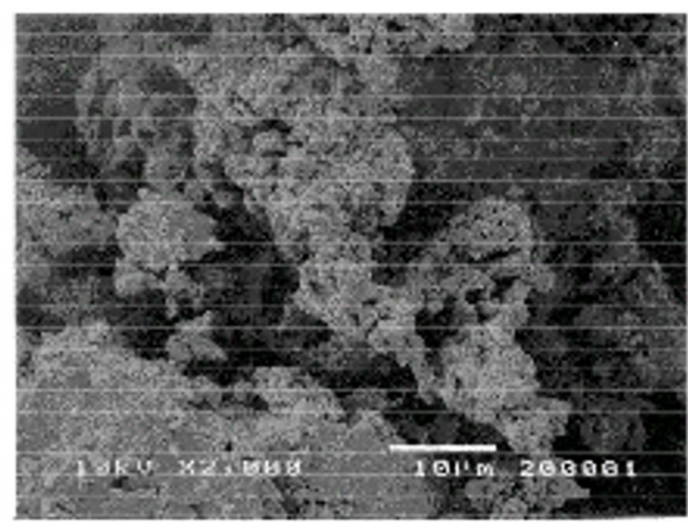

(b) SSA-B

Figure 2. Particles of SSA [11] 


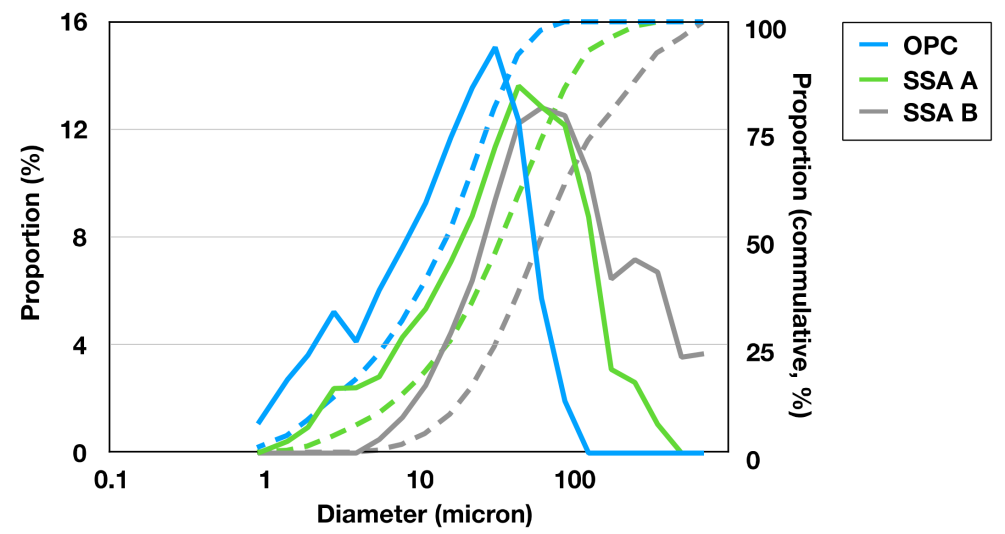

Figure 3. Particle size distributions of ordinary Portland cement and SSAs [11].

\section{Summary of the Tests}

\subsection{Mixtures and Specimens}

Table 5 shows the materials used in this study. Table 6 shows the mix proportions of concrete used in this study. In consideration of the $\mathrm{P}_{2} \mathrm{O}_{5}$ content in each SSA and the results of previously conducted trials on mortar strength and concrete workability, the replacement ratios of SSA-A and SSA-B to cement were set to $10 \%$ and $5 \%$, respectively [10]. The designed strengths of concrete were set to $24 \mathrm{MPa}, 40 \mathrm{MPa}$ and $60 \mathrm{MPa}$. N24 represents an ordinary concrete mixture with a slump of $80 \mathrm{~mm}$. H40 and H60 represent self-compacting concrete mixtures with a slump flow of $600 \mathrm{~mm}$. The air content of each mixture was set to $3.5 \%$ and $4.5 \%$. Two types of specimens were prepared, with $\phi 100 \times 200 \mathrm{~mm}$ cylinders and $100 \times 100 \times 400 \mathrm{~mm}$ beams. The cylinders were made from $4.5 \%$ air mixtures, and the beams were made from both $3.5 \%$ and $4.5 \%$ air mixtures. In order to achieve the designated slump and slump flow values, the dosages of AE agent for all the mixtures, water reducer for N 24, super plasticizer, and viscosity-enhancing agent for $\mathrm{H} 40$ and $\mathrm{H} 60$, were adjusted.

A volume of 30 to $50 \mathrm{~L}$ of concrete was mixed using a $55 \mathrm{~L}$ twin-shaft concrete mixer. For the N24-series mixtures, after dry-mixing for $15 \mathrm{~s}$, water, a water reducer, and an $\mathrm{AE}$ agent were added and mixed for $120 \mathrm{~s}$. For the H40- and H60-series mixture, after dry-mixing for $20 \mathrm{~s}$, water, a super plasticizer, and an AE agent were added and mixed for $180 \mathrm{~s}$.

Table 5. Materials [10,11].

\begin{tabular}{cccc}
\hline Material & & $\begin{array}{c}\text { Specific Gravity } \\
\left(\mathbf{g} / \mathbf{c m}^{3}\right)\end{array}$ & Others \\
\hline Water $(\mathrm{W})$ & Tap water & 1.0 & - \\
\hline Cement (C) & Ordinary Portland cement & 3.15 & F.M.: 3.01 \\
\hline Fine aggregate (S) & River sand & 2.59 & Tight sandstone, \\
Coarse aggregate (G) & Crushed stone & 2.70 & - \\
\hline Sewage sludge ash (SSA) & SSA-A & 2.69 & - \\
\hline Water reducer & SSA-B & 2.34 & Lignin-based \\
\hline Super plasticizer & & 1.25 & Polume: $60.0 \%$ \\
\hline AE agent & & 1.05 & - \\
\hline Viscosity enhancer & & - & Cellulose \\
\hline
\end{tabular}


Table 6. Mix Proportions [10,11].

\begin{tabular}{|c|c|c|c|c|c|c|c|c|c|c|}
\hline & & W/C & W/P & s/a & $\begin{array}{c}W \\
\left(\mathrm{~kg} / \mathrm{m}^{3}\right)\end{array}$ & $\begin{array}{c}\mathrm{C} \\
\left(\mathrm{kg} / \mathrm{m}^{3}\right)\end{array}$ & $\begin{array}{c}\text { SSA } \\
\left(\mathrm{kg} / \mathrm{m}^{3}\right)\end{array}$ & $\begin{array}{c}\mathrm{S} \\
\left(\mathrm{kg} / \mathrm{m}^{3}\right)\end{array}$ & $\begin{array}{c}\mathrm{G} \\
\left(\mathrm{kg} / \mathrm{m}^{3}\right)\end{array}$ & SSA/P \\
\hline N24-0 & 24 & 0.630 & 0.630 & 0.485 & 163 & 259 & - & 892 & 988 & 0 \\
\hline N24-5B & 24 & 0.656 & 0.623 & 0.484 & 166 & 253 & B: 13 & 881 & 980 & 0.05 \\
\hline N24-10A & 24 & 0.677 & 0.608 & 0.481 & 168 & 248 & A: 28 & 869 & 978 & 0.10 \\
\hline $\mathrm{H} 40-0$ & 40 & 0.491 & 0.491 & 0.538 & 185 & 377 & - & 910 & 810 & 0 \\
\hline H40-5B & 40 & 0.504 & 0.479 & 0.530 & 185 & 367 & B: 19 & 889 & 818 & 0.05 \\
\hline H40-10A & 40 & 0.545 & 0.490 & 0.514 & 195 & 358 & A: 40 & 842 & 828 & 0.10 \\
\hline H60-0 & 60 & 0.319 & 0.319 & 0.495 & 175 & 549 & - & 780 & 826 & 0 \\
\hline H60-5B & 60 & 0.356 & 0.338 & 0.501 & 175 & 492 & B: 26 & 798 & 826 & 0.05 \\
\hline H60-10A & 60 & 0.395 & 0.356 & 0.471 & 190 & 481 & A: 53 & 723 & 846 & 0.10 \\
\hline
\end{tabular}

$\mathrm{P}=\mathrm{C}+\mathrm{SSA}, \mathrm{W} / \mathrm{C}$ : water-to-cement ratio in mass, W/P: water-to-powder ratio in mass, s/a: sand-to-total aggregate ratio in absolute volume.

\subsection{Exposure Condition}

After being cured in water at $20^{\circ} \mathrm{C}$ for 28 days, the specimens were left exposed outdoors at two locations, one in Gifu city located in a temperate plain $\left(35^{\circ} 0027^{\prime} 52.47004^{\prime \prime} \mathrm{N}\right.$, $136^{\circ} 44^{\prime} 22.69007^{\prime \prime} \mathrm{E}$ ), and the other in Takayama city situated in a cold mountainous basin $\left(36^{\circ} 10^{\prime} 9.32604^{\prime \prime} \mathrm{N}, 137^{\circ} 14^{\prime} 35.70015^{\prime \prime} \mathrm{E}\right)$. The latter was chosen for its freezing weather during winter that is suitable for the investigation of the SSA concrete resistance to frost attack. Examples of the weather conditions of these two cities during the 17-year exposure period, from November 2015 to March 2016 and August 2016, are shown in Tables 7 and 8 [15].

The highest and the lowest temperatures in the mountainous basin were 2 to 5 and 4 to $8{ }^{\circ} \mathrm{C}$ lower than in the temperate plain, respectively, from autumn to spring. In January and February, it snowed almost every day in the mountainous basin, with the temperature not reaching $0{ }^{\circ} \mathrm{C}$ in half of these months, while there was only one day when the temperature was below $0{ }^{\circ} \mathrm{C}$ in the temperate plain region. Figures 4 and 5 show the two exposure sites. The specimens were left uncovered there for 17 years. Figure 6 shows the appearance of N24-5B and N24-10A left exposed for 17 years in the cold mountainous basin.

Table 7. The Highest and Lowest Temperatures in Two Cities [15].

\begin{tabular}{ccccc}
\hline & \multicolumn{2}{c}{ Takayama (Cold Mountain Region) } & \multicolumn{2}{c}{ Gifu (Temperate Plain Region) } \\
\cline { 2 - 5 } & Max. $\left({ }^{\circ} \mathbf{C}\right)$ & Min. $\left({ }^{\circ} \mathbf{C}\right)$ & Max. $\left({ }^{\circ} \mathbf{C}\right)$ & Min. $\left({ }^{\circ} \mathbf{C}\right)$ \\
\hline Nov. 2015 & 22.2 & 0.4 & 24.8 & 3.9 \\
\hline Dec. 2015 & 19.6 & -4.4 & 22.1 & -0.2 \\
\hline Jan. 2016 & 11.2 & -9.1 & 15.0 & -5.0 \\
\hline Feb. 2016 & 13.1 & -10.3 & 18.2 & -2.3 \\
\hline Mar. 2016 & 20.0 & -5.3 & 22.6 & -0.8 \\
\hline Apr. 2016 & 27.4 & -2.5 & 27.6 & 3.9 \\
\hline May 2016 & 30.8 & 6.3 & 33.3 & 11.4 \\
\hline Jun. 2016 & 30.7 & 4.5 & 33.5 & 20.6 \\
\hline Jul. 2016 & 33.0 & 16.4 & 35.8 & 20.4 \\
\hline Aug. 2016 & 35.8 & 15.3 & 38.5 & 16.5 \\
\hline Sep. 2016 & 33.5 & 12.1 & 34.5 & 8.3 \\
\hline Oct. 2016 & 29.4 & 2.7 & 29.8 &
\end{tabular}


Table 8. Number of Days When the Highest Temperature Was Below $0{ }^{\circ} \mathrm{C}$ and Number of Days of Snowfall [15].

\begin{tabular}{ccccc}
\hline & \multicolumn{2}{c}{ Takayama (Cold Mountain Region) } & \multicolumn{2}{c}{ Gifu (Temperate Plain Region) } \\
\cline { 2 - 5 } & $\begin{array}{c}\text { No. of Days When the Highest } \\
\text { Temperature Was below 0 }{ }^{\circ} \mathrm{C}\end{array}$ & $\begin{array}{c}\text { No. of Days of } \\
\text { Snowfall }\end{array}$ & $\begin{array}{c}\text { No. of Days When the Highest } \\
\text { Temperature Was below 0 }{ }^{\circ} \text { C }\end{array}$ & $\begin{array}{c}\text { No. of Days of } \\
\text { Snowfall }\end{array}$ \\
\hline Nov. 2015 & 0 & 2 & 0 & 0 \\
\hline Dec. 2015 & 2 & 15 & 0 & 0 \\
\hline Jan. 2016 & 12 & 28 & 1 & 7 \\
\hline Feb. 2016 & 13 & 23 & 0 & 5 \\
\hline Mar. 2016 & 2 & 12 & 0 & 2 \\
\hline
\end{tabular}

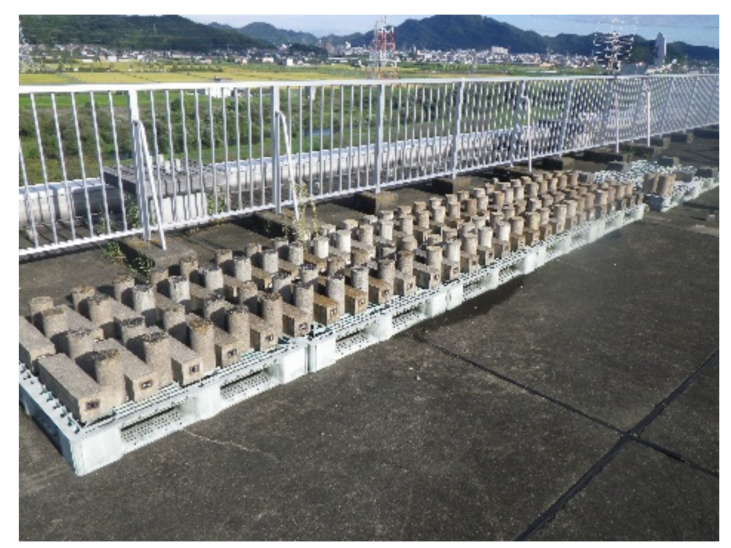

Figure 4. Exposure site in the temperate plain.

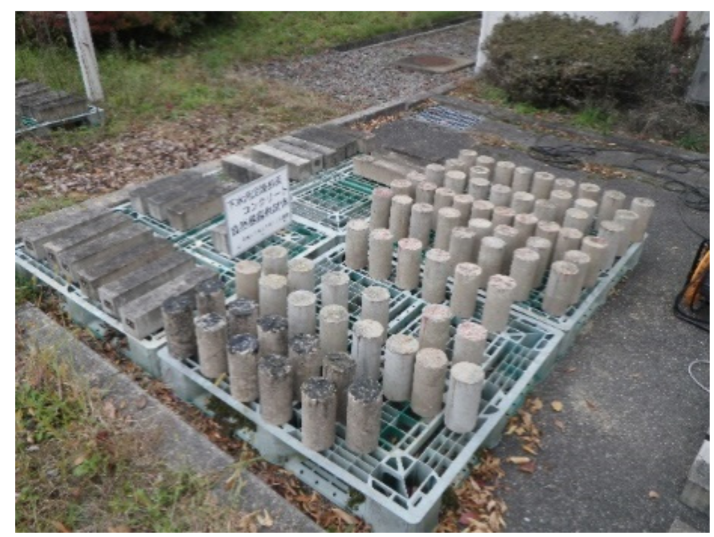

Figure 5. Exposure site in the cold mountainous basin.

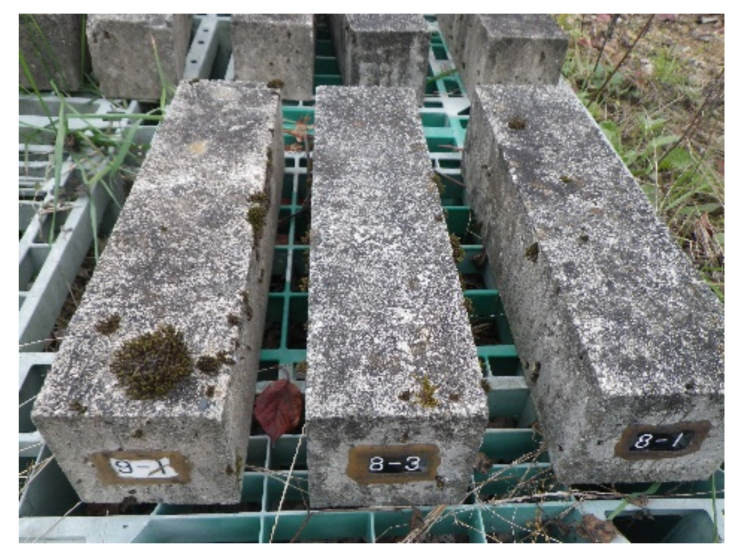

Figure 6. N24-5B and N24-10A exposed in the cold mountainous basin. 


\subsection{Test Items}

To determine the strength of the SSA concrete that had been left exposed in the temperate plain and cold mountain regions for a long time, compressive tests were conducted on the cylindrical specimens $(\phi 100 \times 200 \mathrm{~mm})$ by following JIS A1108 [16], which is equivalent to ISO 1920-4 [17]. The tests were carried out on three cylinders for each mixture of both specimens in the temperate plain and cold mountainous basin after 4 months and 204 months of exposure.

To determine the resistance to frost attack after a long period of exposure, primary flexural resonance frequencies were measured in accordance with JIS A1127 [18] that is equivalent to ASTM C215 [19], and relative dynamic moduli of elasticity were calculated in accordance with JIS A1148 [20], that is equivalent to ASTM C666 [21], after 4 months and 204 months of exposure.

Immediately after the compressive test after 204 months of exposure, the cylindrical specimens tested for compressive strength were split along the longitudinal axis by a compression testing machine. A $1 \%$ ethyl alcohol solution of phenolphthalein was sprayed on the split surfaces for the measurement of the carbonation depth. The distances from both side faces of the specimens to the boundaries of the reddish-purple areas were measured with a caliper at 50,100, and $150 \mathrm{~mm}$ from the placing surface, i.e., at a total of six points, and the average depth was calculated for each specimen.

Specimens N24-0 and N24-10A left exposed in the temperate plain for 204 months were observed with SEM and EPMA. Furthermore, the compositions of the hardened cement near the surface and in the center of the specimens N24-0, N24-10A, N60-0, and N60-10A exposed in the temperate plain for 204 months were analyzed by powder X-ray diffraction (XRD). Figure 7 illustrates the SEM and EEPMA observation plane and the sampling points for the XRD analysis. For the XRD analysis, the concrete sample pieces of $20 \times 20 \times 50 \mathrm{~mm}$ were coarsely ground after being dried at 40 degree Celsius for $24 \mathrm{~h}$, sieved with a $105 \mu \mathrm{m}$ sieve to remove aggregates as much as possible, and pulverized. The $\mathrm{X}$-ray output was $15 \mathrm{~mA}$ and $40 \mathrm{kV}$.

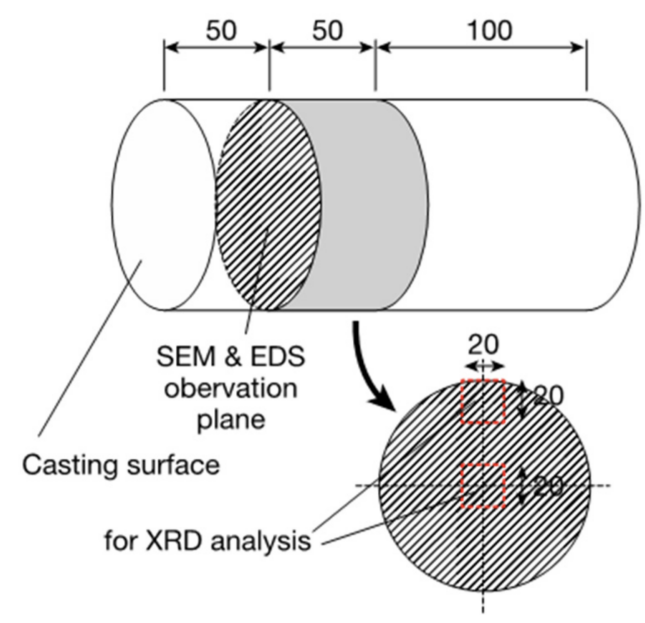

Figure 7. SEM and EPMA observation plane and sampling points for XRD analysis.

Figure 8 illustrates the schedule for this study. 


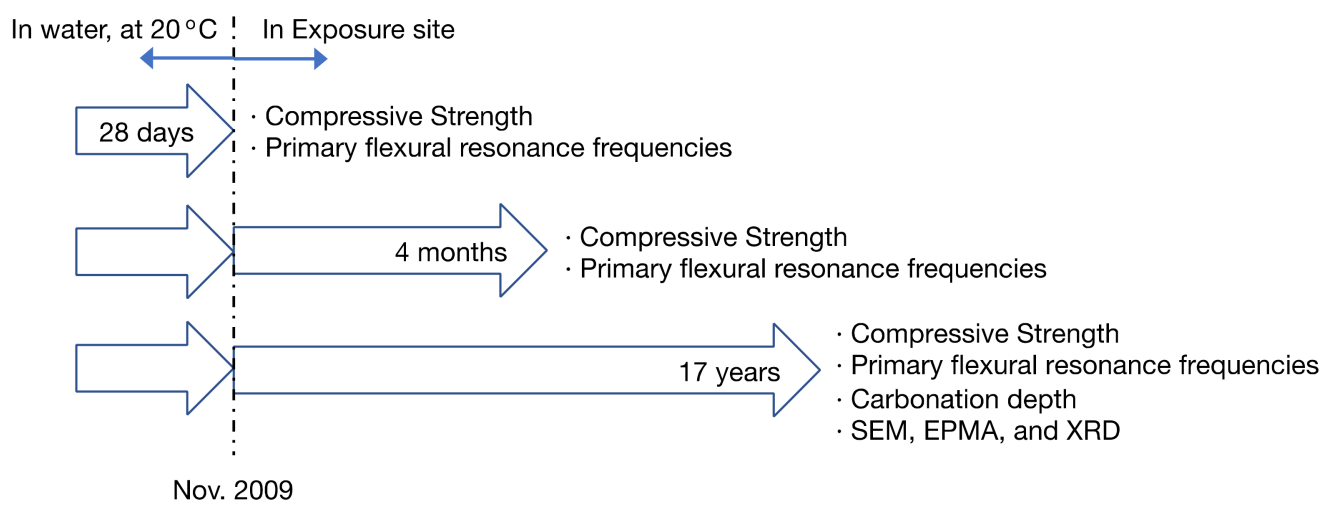

Figure 8. Schedule for this study.

\section{Results}

The results of the tests carried out after 4 months and 204 months of exposure (specimens were 5 and 205 months old, respectively) are shown below. Since the exposure test was started in November, the results after 4 months (specimens at the age 5 months) were obtained after the first winter.

\subsection{Compressive Strength}

Figure 9 shows the compressive strength of the N24, H40, and H60 series. For each of the N24 and H40 series, the mixtures showed the same level of strength, despite the varying unit cement contents throughout the exposure period, except for H40-10A-M that had a lower strength at the age of 204 months. We assumed that the pozzolanic reaction of amorphous $\mathrm{SiO}_{2}$ in the sludge ash compensated for the reduced amount of cement. The compression strength of Series H60 with a larger SSA replacement ratio was reduced after 4 months. As previously reported [9-11], the setting time of Series H60 was markedly slowed down by the mixing of SSA, and the delay depended on the amount of phosphorus in the concrete mixture. It is also possible that the pozzolanic reaction had not progressed sufficiently at the age of 4 months due to the relatively large amount of SSA in the H60 series.
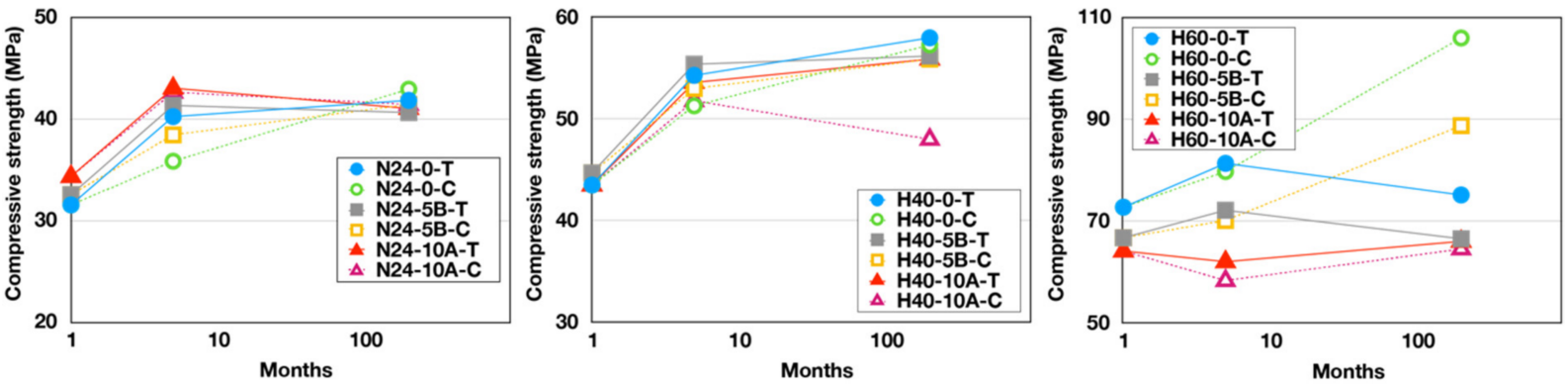

Figure 9. Compressive strength (T: temperate plain region, C: cold mountain region).

When we examined the data at the age of 4 months, the specimens of all the mixtures in the cold mountain region had a lower compressive strength than the specimens in the temperate plain region, regardless of the presence of SSA. This was assumed to be due to the fact that the specimens were left in the cold climate in the mountain basin area before hydration of the cement and reaction with SSA had fully progressed, and the low temperatures had inhibited further hydration and reaction during the 4 months. After 17 years, there was no distinct difference in the strength of concrete between the two exposure sites.

It is not clear why the strength of H40-10A-M decreased and why the strength of H60-0-M and H60-5B-M increased remarkably after 17 years. 


\subsection{Relative Dynamic Modulus of Elasticity}

Figure 10 shows the relative dynamic moduli of elasticity of the beam specimens. In Series N24 and H40, no clear influence of the SSA and air contents on the relative dynamic modulus of elasticity was discernible. As for Series H60, a substantial drop was noticeable in the relative dynamic modulus of elasticity of the specimens in the cold mountain region with the air volume of $3.5 \%$ at the age of 4 months. This was again assumed to be due to the effect of immature exposure to the cold climate of the relatively cement-rich mixture before it reached a full hydration state, as previously discussed in Section 4.1. Similar to the tendency in compressive strength mentioned in Section 4.1, the specimens in the cold mountain region had higher relative dynamic moduli of elasticity than the specimens in the plane region after 17 years of exposure. All the specimens in the cold mountain region, including those of the mixture with 3.5\% air content, kept a relative dynamic modulus of elasticity of more than $85 \%$, from which we can conclude that all mixtures were sufficiently resistant to frost attack.
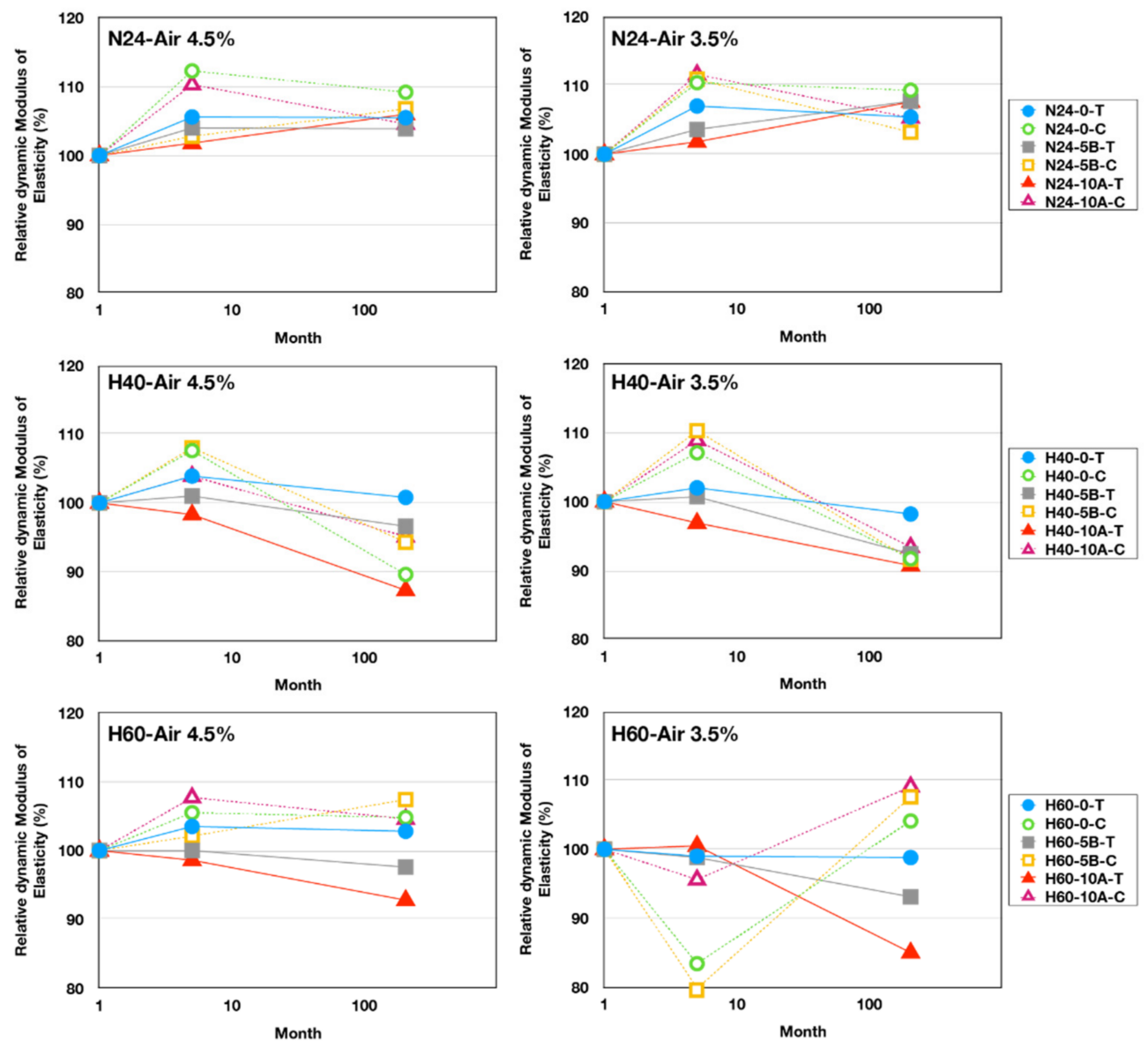

Figure 10. Relative dynamic modulus of elasticity (T: temperate plain region, C: cold mountain region).

\subsection{Carbonation Resistance}

Figure 11 shows the results of carbonation depth measurements. Contrary to the concern that the pozzolanic reaction in SSA might have intensified carbonation, the carbonation depth was small in all mixtures. There was a general tendency of the specimens in the cold mountain region to have a smaller carbonation depth than the specimens in the temperate plain region. This is attributable to prolonged periods of high humidity, because of the cold climate of the mountain basin with heavy snowfall and short periods of clear sky. 


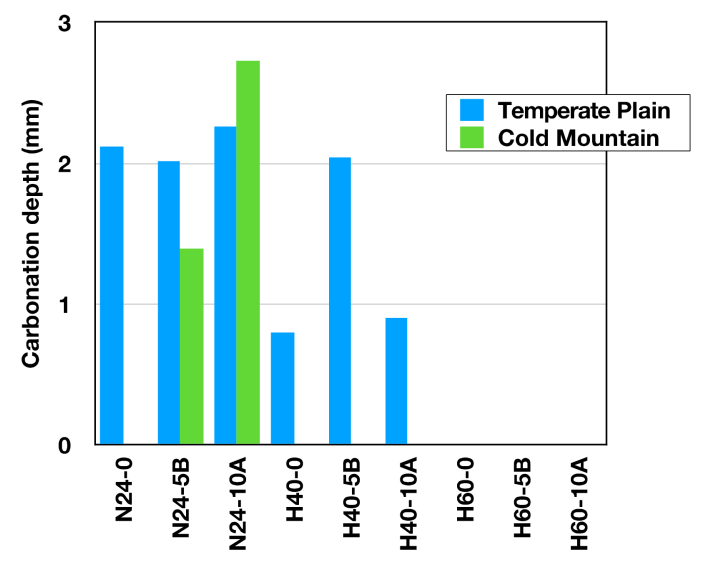

Figure 11. Carbonation depth (after 17 years of exposure).

\section{Discussion}

\subsection{Durability of SSA Concrete}

According to the estimation by Hasegawa et al. [22] using a calculation method as specified by the Architectural Institute of Japan [23], the climatic conditions of the exposure sites in the temperate plain and cold mountain regions correspond, respectively, to 2 and 29 cycles/year of freezing and thawing in the ASTM C666 test. Thus, the specimens left in the two sites for 17 years were exposed to 34 and 493 ASTM C666 cycles, respectively. It can be said that the frost resistance of SSA concrete is sufficiently high, because the relative dynamic modulus of elasticity hardly decreased in spite of the severe conditions of the cold region (see Figure 10).

Generally, the carbonation progress is expressed as follows:

$$
y=a \sqrt{t}
$$

where:

$y$-Carbonation depth

$a$-Carbonation rate coefficient

t-Time

According to the JSCE model code, the predicted value of the carbonation rate coefficient $a_{p}$ is as follows [24]:

$$
a_{p}=-3.57+9.0 \mathrm{~W} / \mathrm{C}
$$

Table 9 shows the carbonation rate coefficients $a$ of all the mixtures calculated from the measured carbonation depths using Equation (1) in comparison with predicted values $a_{p}$ calculated from the respective water-cement ratios of the mixtures using Equation (2). Following the rule that fly ash is not regarded as cement in application of Equation (2), the water-cement ratios were computed without including the amounts of SSA.

Table 9. Carbonation rate coefficient $(\mathrm{mm} \sqrt{\text { year }})$.

\begin{tabular}{cccc}
\hline \multirow{2}{*}{ Mixture } & \multicolumn{2}{c}{ Measured } & \multirow{2}{*}{ Predicted } \\
\cline { 2 - 3 } & Cold Mountain Region & Temperate Plain Region & \\
\hline N24-0 & 0.00 & 0.51 & 2.10 \\
\hline N24-5B & 0.34 & 0.49 & 2.33 \\
\hline N24-10A & 0.66 & 0.55 & 2.51 \\
\hline H40-0 & 0.00 & 0.19 & 0.85 \\
\hline H40-5B & 0.00 & 0.49 & 0.97 \\
\hline H40-10A & 0.00 & 0.22 & 1.33 \\
\hline
\end{tabular}


Table 9. Cont.

\begin{tabular}{cccc}
\hline \multirow{2}{*}{ Mixture } & \multicolumn{2}{c}{ Measured } & \multirow{2}{*}{ Predicted } \\
\cline { 2 - 3 } & Cold Mountain Region & Temperate Plain Region & \\
\hline H60-0 & 0.00 & 0.00 & - \\
\hline H60-5B & 0.00 & 0.00 & - \\
\hline H60-10A & 0.00 & 0.00 & - \\
\hline
\end{tabular}

According to Equation (2), no carbonation would occur in concrete with a watercement ratio of $40 \%$ or less. As expected, Series $\mathrm{H} 60$ with a very low water-cement ratio was free of carbonation. All the other specimens showed a smaller carbonation rate coefficient than the expected value. This allows us to conclude that the use of SSA does not have the effect of accelerating carbonation in concrete.

\subsection{Microstructural and Chemical Analyses}

In order to discuss the above results in more detail, microstructural and chemical analyses were carried out.

Figure 12 shows examples of SEM images of N24-10A. No signs of deterioration such as cracks in the aggregate with a gelatinous substance and gaps around the aggregates due to cement paste expansion were discernible in the observed planes. The possibility of delayed ettringite formation (DEF) was anticipated because of the alumina richness of SSA, as shown in Table 1; indeed some needle-like crystals were visible in air voids and other cavities. An EPMA analysis indicated the ratios of $\mathrm{Al} / \mathrm{Ca}=1 / 3$ and $\mathrm{S} / \mathrm{Ca}=1 / 2$ (Figure 13), which confirmed that the crystals were ettringite. However, no signs of deterioration starting from these crystals were observed.
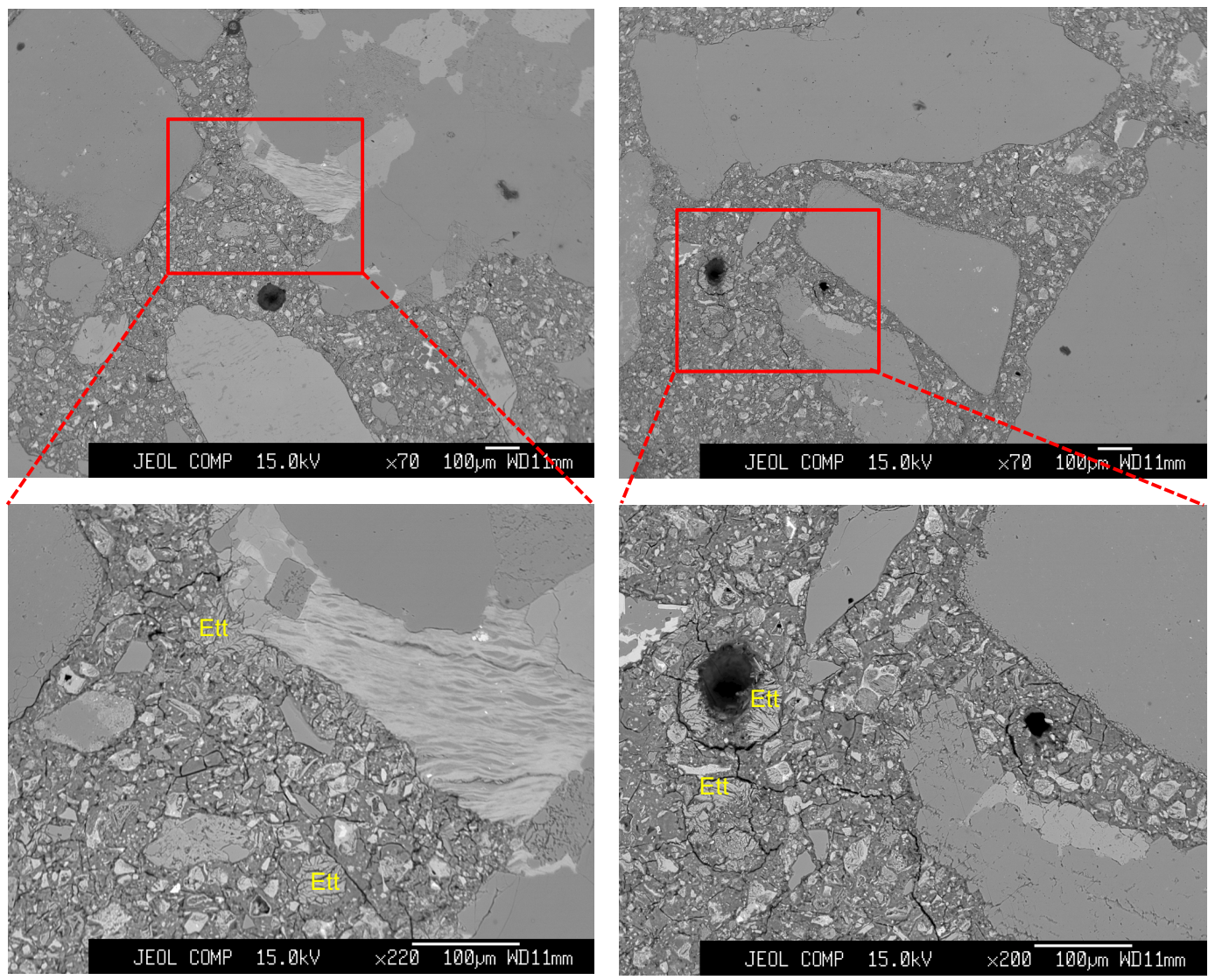

Ett: Ettringite

Ett: Ettringite

Figure 12. SEM images of N24-10A. 

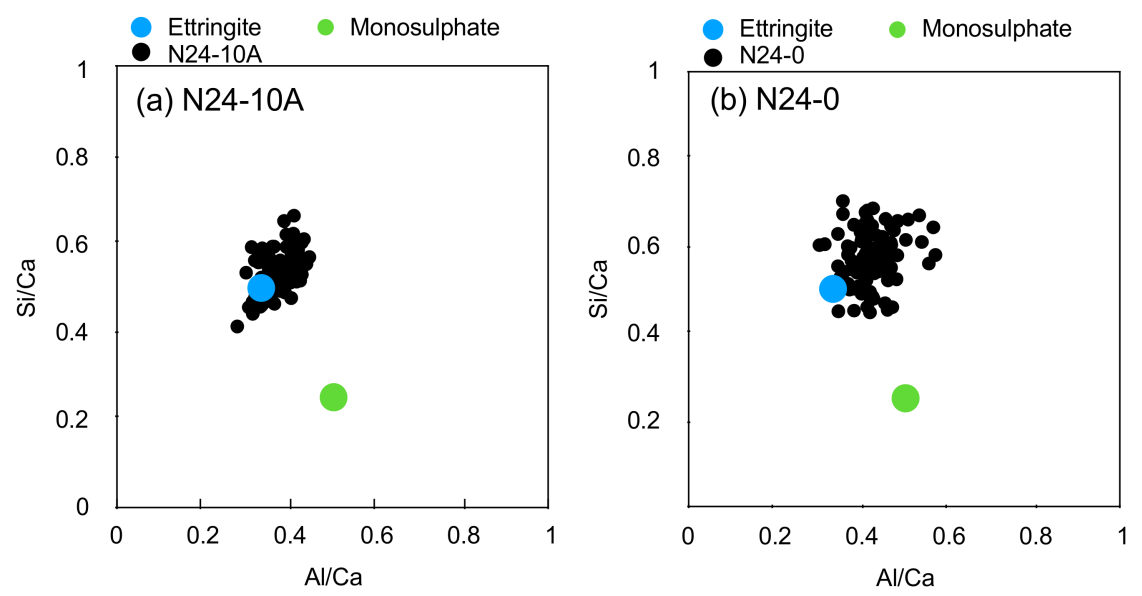

Figure 13. Compositions of crystals in air voids ((a) N24-10A, (b) N24-0).

Ettringite crystals were found in air voids and other cavities also in N24-0 without SSA, as shown in the SEM images of Figure 14. This clearly indicates that the presence of SSA does not increase the risk of DEF-related deterioration of concrete.

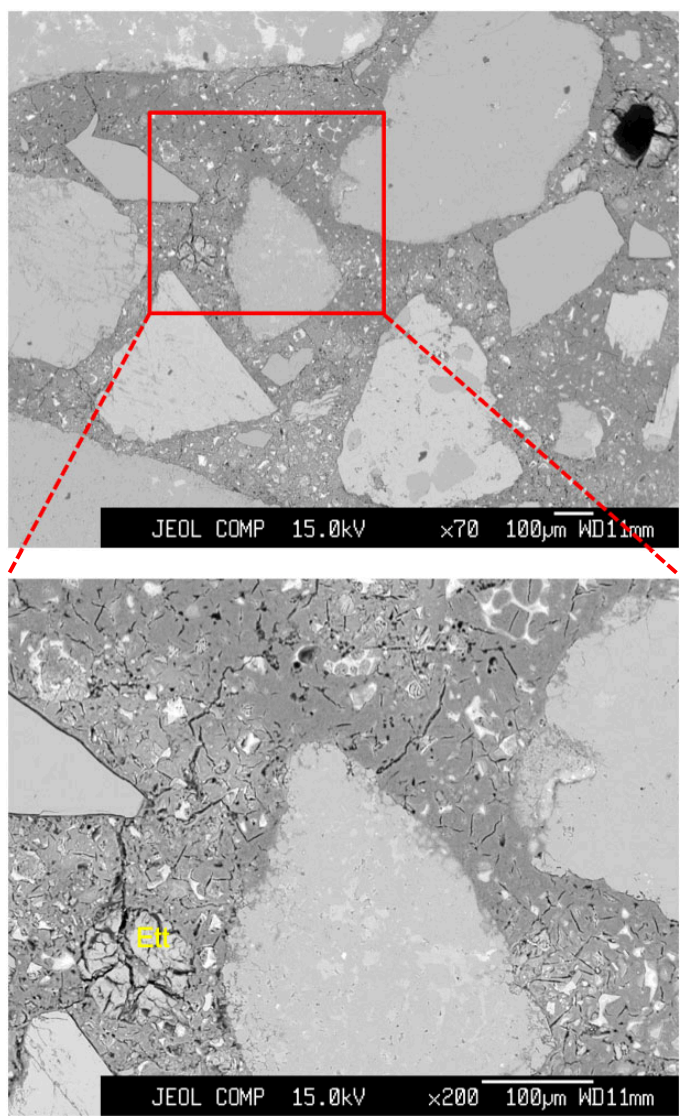

Ett: Ettringite

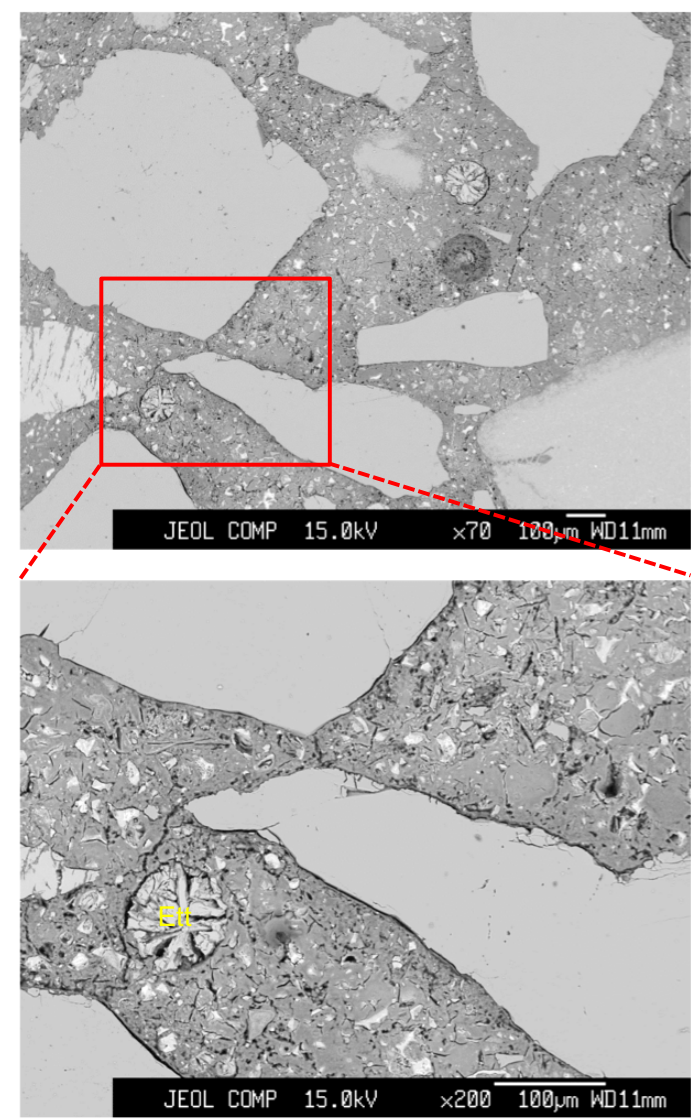

Ett: Ettringite

Figure 14. SEM images of N24-0.

Figure 15 shows the results of the XRD analysis of N24-10A, N24-0, H60-10A, and H600 . The only notable difference is that SSA concrete contained a small amount of crystalline calcium aluminosilicate hydrate (Katoite: $\mathrm{C}_{3} \mathrm{ASH}_{4}$ ). Katoite has been reported to form in fly ash cement concrete [25]. In our case, it was assumed that the high content of $\mathrm{Al}_{2} \mathrm{O}_{3}$ in SSA led to the formation of Katoite. No effects of the presence of SSA on the formation of ettringite were observed in the XRD analysis. Calcite $\left(\mathrm{CaCO}_{3}\right)$ was detected mainly on the 
specimen surface, which is assumed to be the result of carbonation of Portlandite $\left(\mathrm{Ca}(\mathrm{OH})_{2}\right)$. The mixing of SSA is unlikely to have influenced the amount of Calcite formation.

The results of these analyses indicated that there was no adverse effect of the use of SSA as a cement replacement material on the formation of cement hydrates. Given the result of the strength test and the absence of deterioration by carbonation and frost attack, it can be considered that SSA concrete is sufficiently durable and fit for practical use.

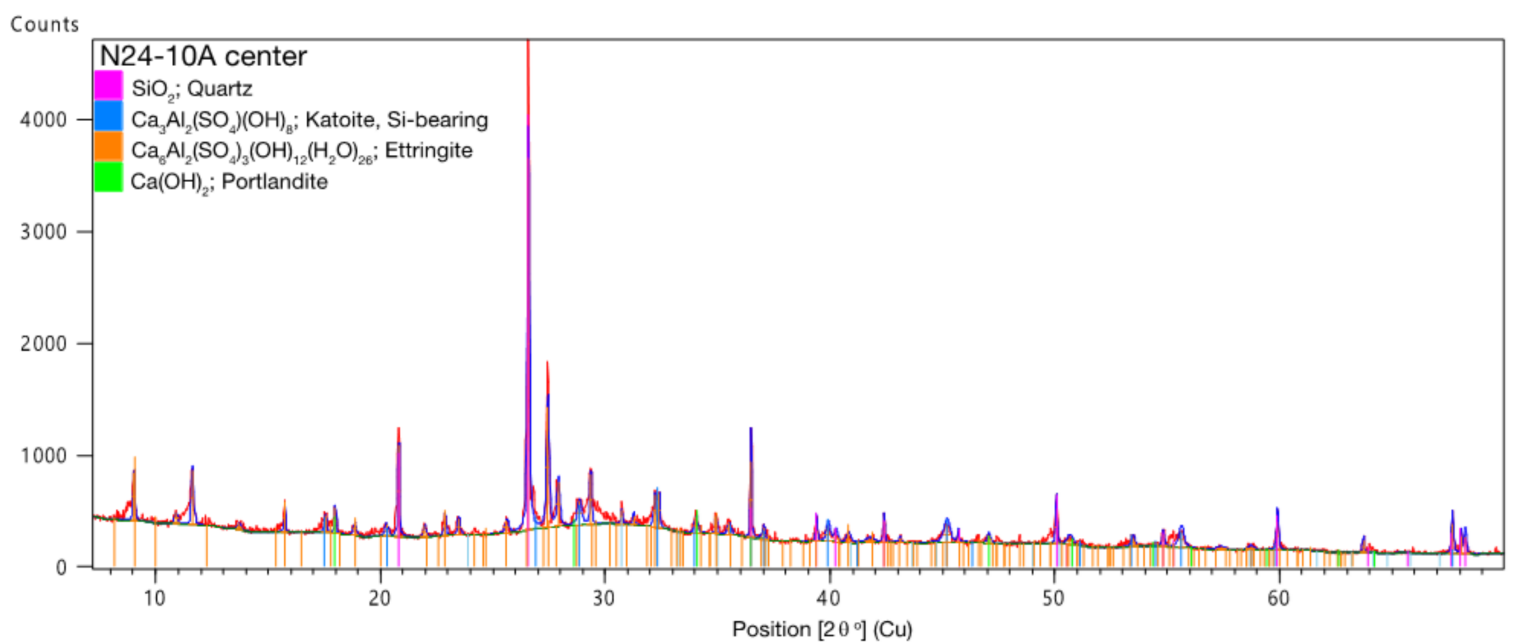

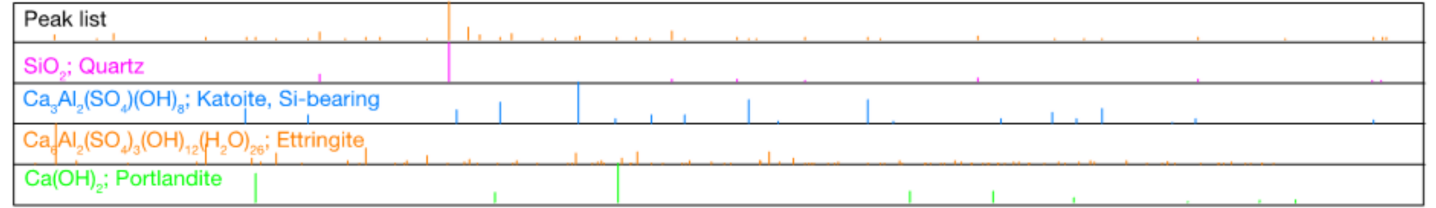

(a) Center of N24-10A

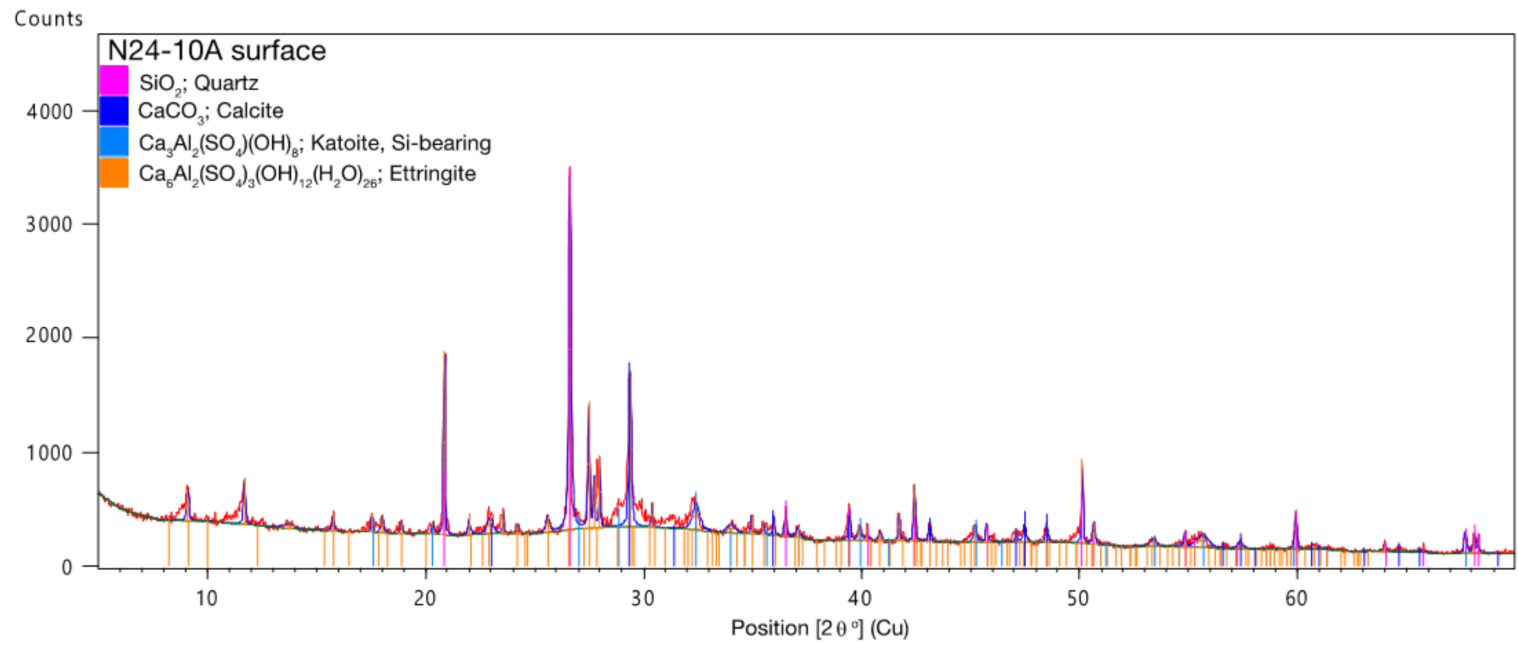

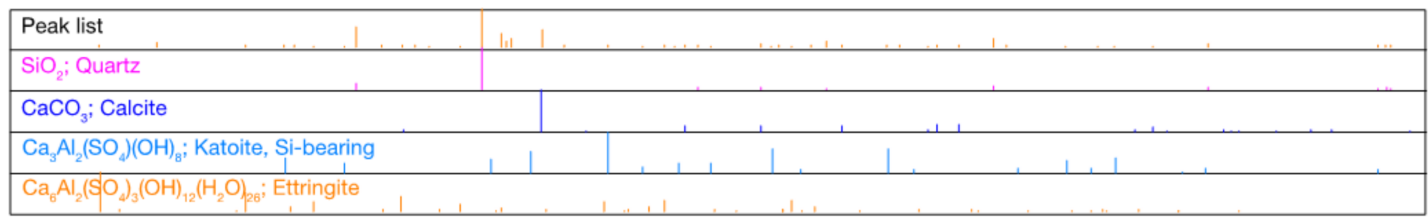

(b) Surface of N24-10A

Figure 15. Cont. 


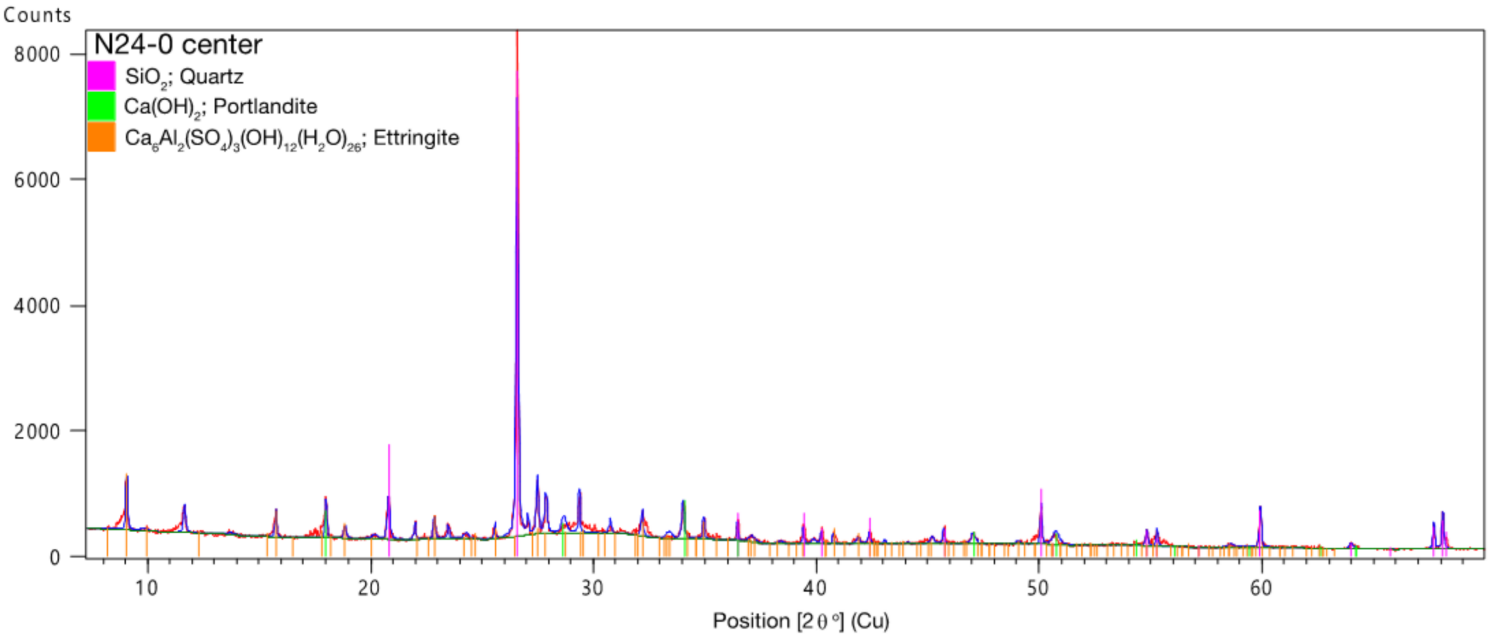

\begin{tabular}{|l|l|l|}
\hline Peak list & \\
\hline $\mathrm{SiO}_{2} ;$ Quartz & & \\
\hline $\mathrm{Ca}(\mathrm{OH})_{2} ;$ Portlandite & & \\
\hline $\mathrm{Ca} \mid \mathrm{Al}_{2}\left(\mathrm{SO}_{4}\right)_{3}(\mathrm{OH})_{12}\left(\mathrm{H}_{2} \mathrm{O}\right)_{26} ;$ Ettringite & \\
\hline
\end{tabular}

(c) Center of N24-0

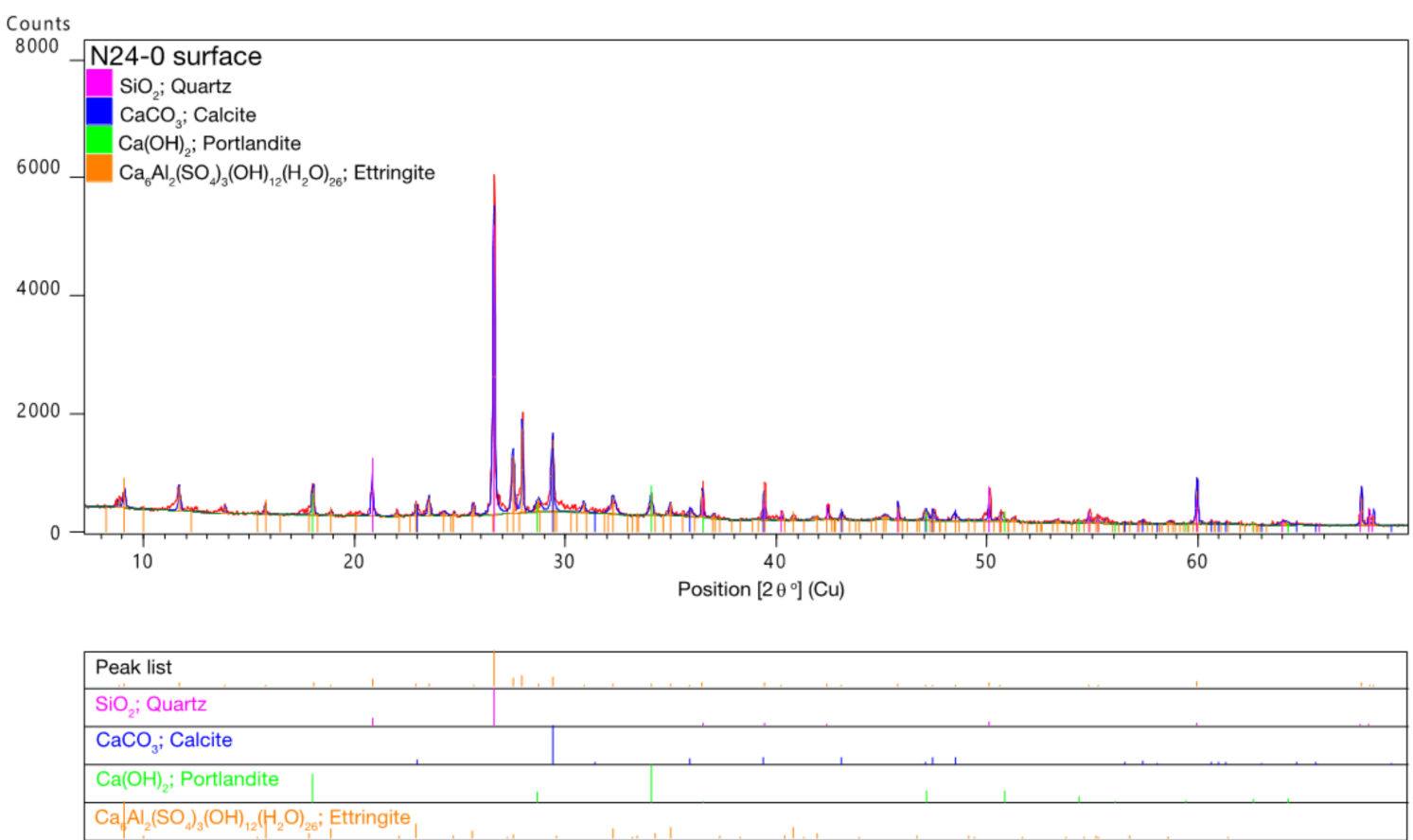

(d) Surface of N24-0

Figure 15. Cont. 


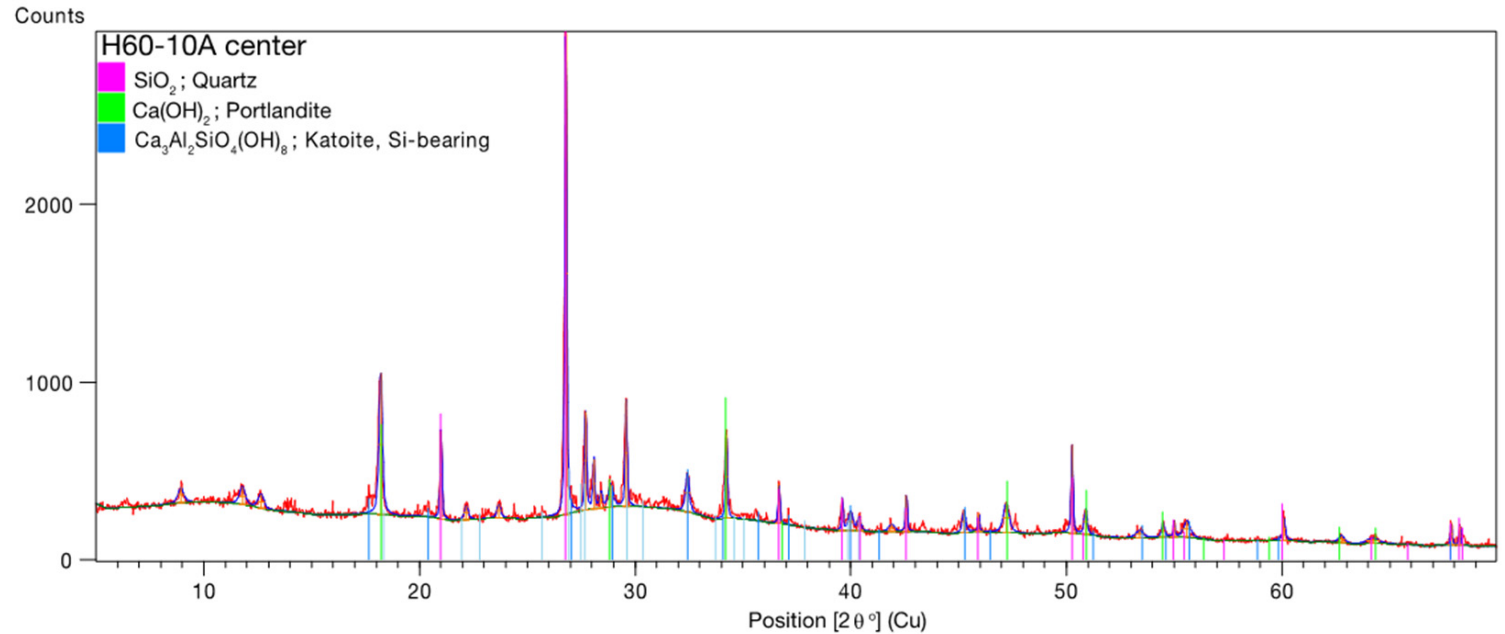

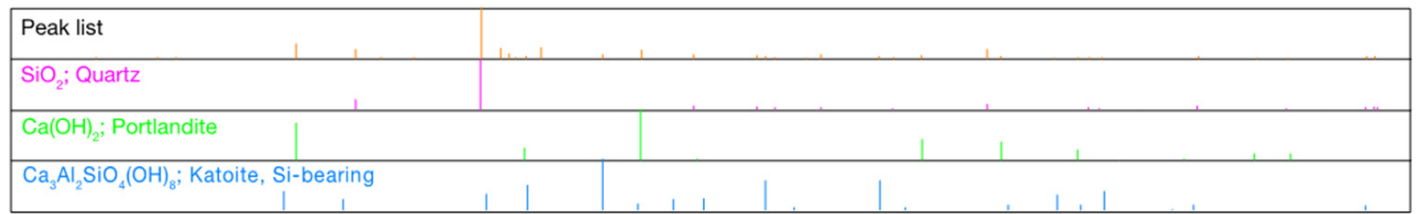

(e) Center of H60-10A

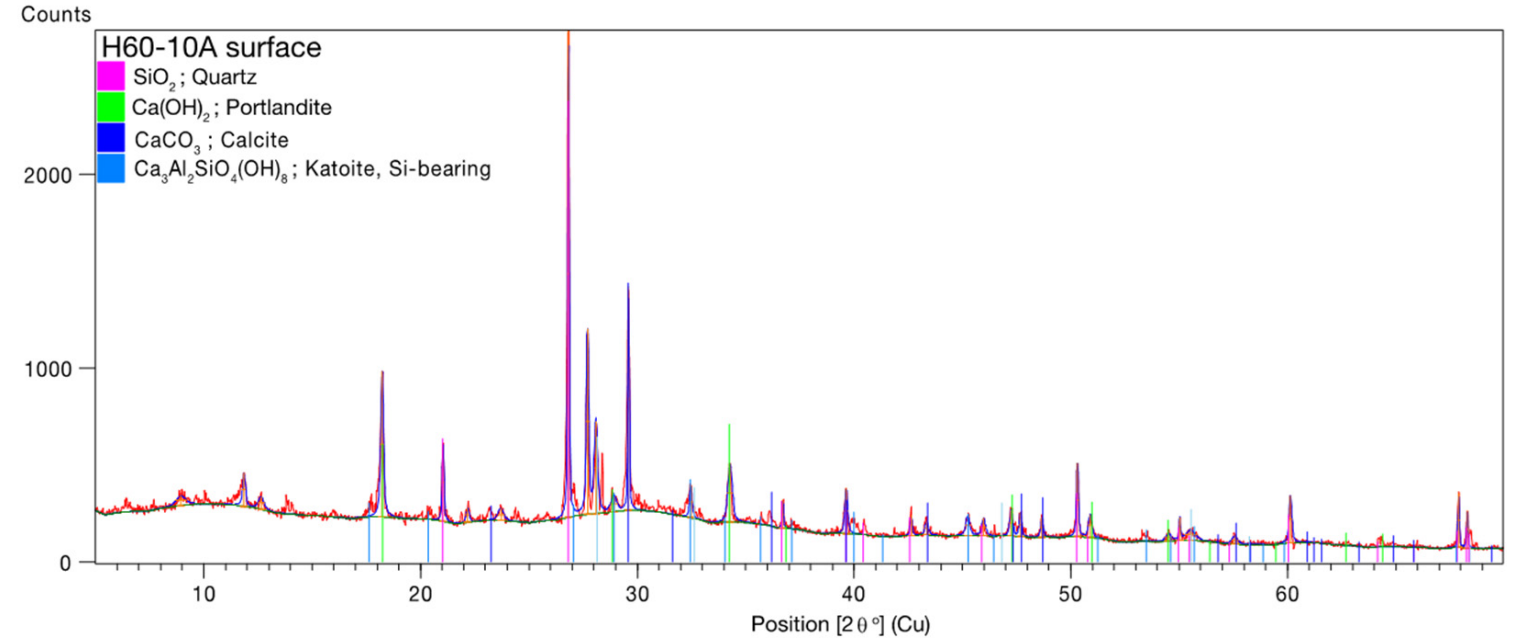

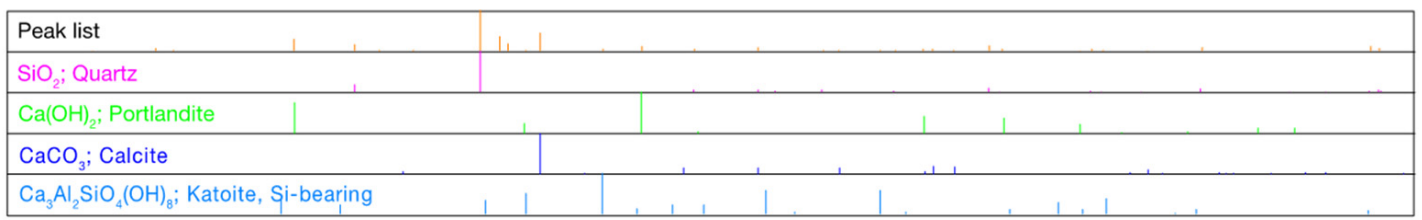

(f) Surface of H60-10A

Figure 15. Cont. 


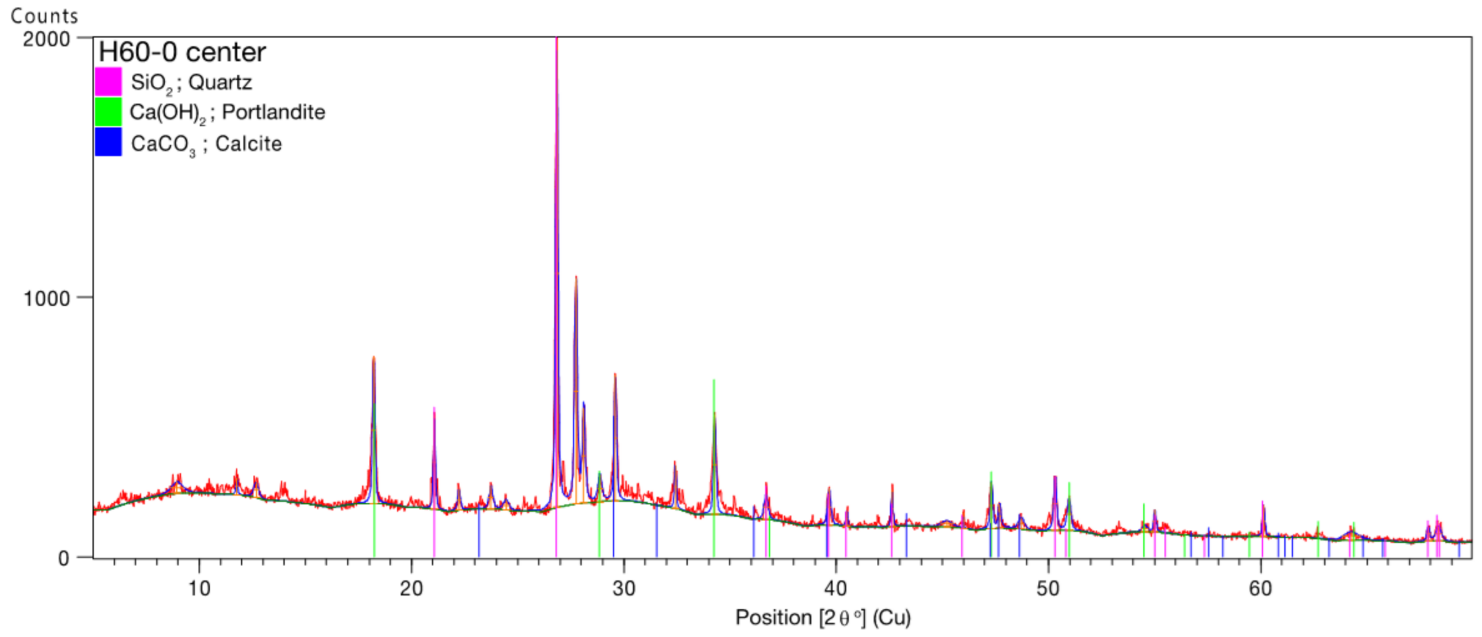

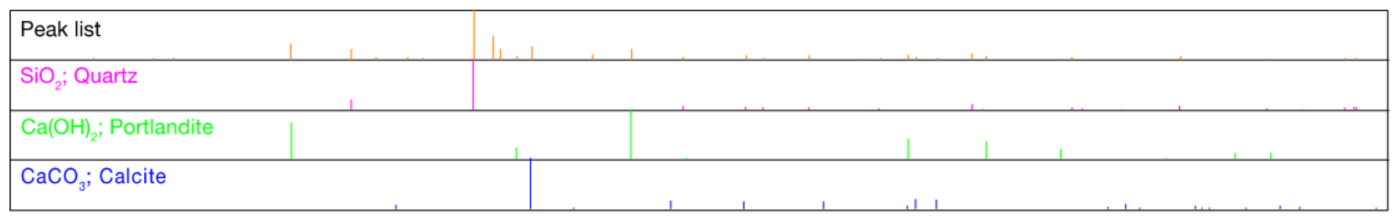

(g) Center of H60-0

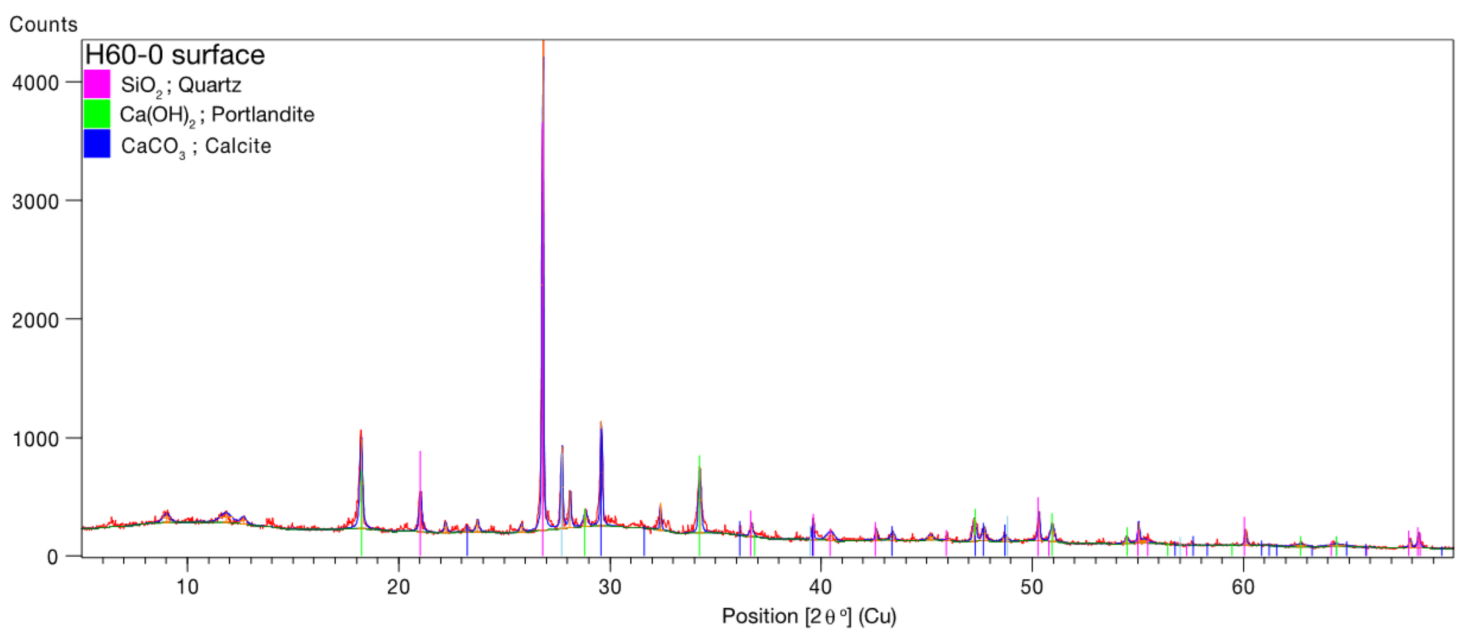

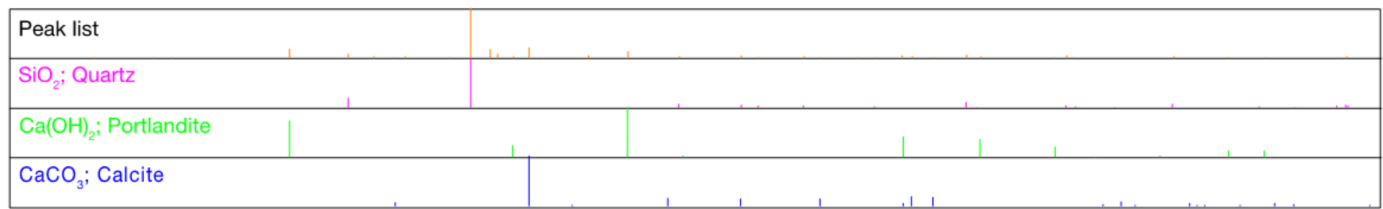

(h) Surface of H60-0

Figure 15. Results of XRD analysis. (a) Center of N24-10A, (b) surface of N24-10A, (c) center of N24-0, (d) surface of N24-0, (e) center of H60-10A, (f) surface of H60-10A, (g) center of H60-0, (h) surface of H60-0.

\section{Conclusions}

This study was conducted on concrete using sewage sludge ash (SSA) with the aim to find an efficient use of SSA as a cement replacement material. Concrete specimens with three degrees of strength were made from two different SSAs and left exposed in temperate plain and cold mountain regions for a prolonged period of time to investigate the long-term properties of SSA concrete. After 17 years of exposure, the specimens were examined 
for changes in compressive strength and relative dynamic modulus of elasticity. The carbonation depth was measured, and SEM observation and XRD analysis were conducted. The results of this study can be summarized as follows:

It was confirmed that SSA concrete basically maintained its strength after 17 years of exposure.

No significant drop in relative dynamic modulus of elasticity was detected in SSA concrete left in a cold mountain region, despite the expectation that it would be exposed to a considerable number of freeze-and-thaw cycles. It was also confirmed that the SSA concrete exhibited high durability against carbonation.

The small amount of Katoite detected in the hardened cement/SSA mixture was probably due to the high content of $\mathrm{Al}_{2} \mathrm{O}_{3}$ in SSA. No abnormal formation of ettringite was observed.

Therefore, it can be concluded that the durability of SSA concrete is as high as that of traditional concrete.

Author Contributions: The following contribution were made by the authors: design and initiation of exposure test in 2009, W.K.; conduct of experiments since 2016, K.K.; writing, K.K.; review and editing, all authors. All authors have read and agreed to the published version of the manuscript.

Funding: This research received no external funding.

Acknowledgments: We are grateful to S. Nozaki (Gifu Prefecture) who kindly allowed us to use the specimens for this study, and to T. Nojiri (formerly Chuken Consultant Co. ltd.) who took the great trouble of digging out the 17-year-old data.

Conflicts of Interest: The authors declare no conflict of interest.

\section{References}

1. Bhatty, J.I.; Reid, K.J. Compressive Strength of Municipal Sludge Ash Mortars. ACI Mater. J. 1989, 86, $394-400$.

2. Monzó, J.; Payá, J.; Borrachero, M.V.; Córcoles, A. Use of sewage sludge ash(SSA)-cement admixtures in mortars. Cem. Concr. Res. 1996, 26, 1389-1398. [CrossRef]

3. Cyr, M.; Coutand, M.; Clastres, P. Technological and environmental behavior of sewage sludge ash (SSA) in cement-based materials. Cem. Concr. Res. 2007, 37, 1278-1289. [CrossRef]

4. Mejdi, M.; Saillio, M.; Chaussadent, T.; Divet, L.; Tagnit-Hamou, A. Hydration mechanisms of sewage sludge ashes used as cement replacement. Cem. Concr. Res. 2020, 135, 106115. [CrossRef]

5. Lynn, C.J.; Dhir, R.K.; Ghataora, G.S.; West, R.P. Sewage sludge ash characteristics and potential for use in concrete. Constr. Build. Mater. 2015, 98, 767-779. [CrossRef]

6. Chen, Z.; Poon, C.S. Comparative studies on the effects of sewage sludge ash and fly ash on cement hydration and properties of cement mortars. Constr. Build. Mater. 2017, 154, 791-803. [CrossRef]

7. Chakraborty, S.; Jo, B.W.; Jo, J.H.; Baloch, Z. Effectiveness of sewage sludge ash combined with waste pozzolanic minerals in developing sustainable construction material: An alternative approach for waste management. J. Clean. Prod. 2017, 153, 253-263. [CrossRef]

8. Lu, J.X.; Zhou, Y.; He, P.; Wang, S.; Shen, P.; Poon, C.S. Sustainable reuse of waste glass and incinerated sewage sludge ash in insulating building products: Functional and durability assessment. J. Clean. Prod. 2019, 236, 117635. [CrossRef]

9. Koyanagi, W.; Nozaki, S.; Ozawa, M.; Honda, K. Leaching of incinerated sewage ash and some properties of the ash mixed mortar. Cem. Sci. Concr. Technol. 1998, 52, 374-379. (In Japanese)

10. Nojiri, T.; Koyanagi, W.; Nozaki, S.; Tokuda, S. Effective Use of Incinerated Sewage Sludge in Concrete. Proc. Jpn. Concr. Inst. 2000, 22, 43-48. (In Japanese)

11. Sewerage Division, Civil Engineering Department, Gifu Prefecture. Report on Survey on Effective Utilization of Sewage Sludge; Sewerage Division, Civil Engineering Department, Gifu Prefecture: Gifu, Japan, 2000. (In Japanese)

12. Hara, Y.; Kobayashi, K. Long-term properties of concrete with incineration sewage ash. Proc. Jpn. Concr. Inst. 2017, 39, 1597-1602. (In Japanese)

13. Japan Cement Association. JCAS I-11-1981 The Method of Chemical Analysis of Raw Material and Dust; Japan Cement Association: Tokyo, Japan, 1981. (In Japanese)

14. Japan Cement Association. JCAS I-51-1981 The Analysis Method of Trace Elements in Cement and Raw Materials of Cement; Japan Cement Association: Tokyo, Japan, 1981. (In Japanese)

15. Japan Meteorological Agency. Available online: http://www.data.jma.go.jp/obd/stats/etrn/index.php (accessed on 1 March 2021). 
16. Japanese Industrial Standards Committee. JIS A1108 Method of Test for Compressive Strength of Concrete; Japanese Industrial Standards Committee: Tokyo, Japan, 2006.

17. International Organization for Standardization. ISO 1920-4 Testing of Concrete-Part. 4: Strength of Hardened Concrete; International Organization for Standardization: Tokyo, Japan, 2005.

18. Japanese Industrial Standards Committee. JIS A1127 Methods of Test for Dynamic Modulus of Elasticity, Rigidity and Poisson's Ratio of Concrete by Resonance Vibration; Japanese Industrial Standards Committee: Tokyo, Japan, 2010.

19. ASTM International. ASTM C215 Standard Test. Method for Fundamental Transverse, Longitudinal, and Torsional Frequencies of Concrete Specimens; ASTM International: West Conshohocken, PA, USA, 2008.

20. Japanese Industrial Standards Committee. JIS A1148 Method of Test for Resistance of Concrete to Freezing and Thawing; Japanese Industrial Standards Committee: Tokyo, Japan, 2010.

21. ASTM International. ASTM C666/C666M Standard Test. Method for Resistance of Concrete to Rapid Freezing and Thawing; ASTM International: West Conshohocken, PA, USA, 2015.

22. Hasegawa, T.; Senbu, O.; Fukuyama, T. Comparison of the estimation results of service life related to frost damage of concrete obtained from the representative estimation methods using climatic data of several observation periods. Proc. Jpn. Concr. Inst. 2015, 37, 859-864. (In Japanese)

23. Architectural Institute of Japan. Recommendations for Durability Design and Construction Practice of Reinforced Concrete Buildings; Maruzen: Tokyo, Japan, 2016; pp. 140-148. (In Japanese)

24. Japan Society of Civil Engineers. Standard Specifications for Concrete Structures-2017, Design; Maruzen: Tokyo, Japan, 2018; pp. 155-156. (In Japanese)

25. Goñi, S.; Guerrero, A.; Luxán, M.P.; Macías, A. Activation of the fly ash pozzolanic reaction by hydrothermal conditions. Cem. Concr. Res. 2003, 33, 1399-1405. [CrossRef] 